\title{
Sequential analysis of biomarkers in cerebrospinal fluid and serum during invasive meningococcal disease
}

\author{
O. Beran • D. A. Lawrence $\cdot$ N. Andersen • \\ O. Dzupova • J. Kalmusova • M. Musilek $\cdot$ M. Holub
}

Received: 1 October 2008 / Accepted: 15 January 2009 / Published online: 10 February 2009

(C) The Author(s) 2009. This article is published with open access at Springerlink.com

\begin{abstract}
The aim of the present study was to determine the profile of different inflammatory molecules in serum and cerebrospinal fluid (CSF) during invasive meningococcal disease (IMD). Their relationship with IMD severity was also assessed. A cohort of 12 patients with IMD was investigated. Paired serum and CSF samples were obtained at the time of diagnostic and follow-up lumbar puncture and were examined using Luminex ${ }^{\circledR}$ analysis. IMD severity correlated with serum interleukin-6 (IL-6) and interleukin-1 receptor antagonist (IL-1ra) on admission. Furthermore, the CSF levels of IL-1 $\beta$, IL-1ra, IL-6, IL-8, macrophage inflammatory protein-1 $\beta$ (MIP-1 $\beta$ ), and monocyte chemoattractant protein-1 (MCP-1) were significantly higher than
\end{abstract}

\section{O. Beran · M. Holub}

1st Medical Faculty, Teaching Hospital Bulovka,

3rd Department of Infectious and Tropical Diseases,

Charles University in Prague,

Prague, Czech Republic

D. A. Lawrence $\cdot N$. Andersen

Wadsworth Center, New York State Department of Health,

Albany, USA

O. Dzupova

3rd Medical Faculty, Teaching Hospital Bulovka,

Department of Infectious Diseases, Charles University in Prague,

Prague, Czech Republic

J. Kalmusova $\cdot$ M. Musilek

National Institute of Public Health,

National Reference Laboratory for Meningococcal Infections,

Prague, Czech Republic

M. Holub ( $\square)$

3rd Department of Infectious and Tropical Diseases,

Teaching Hospital Bulovka,

Budínova 2,

Prague 8180 81, Czech Republic

e-mail: michal.holub@1f1.cuni.cz their respective serum levels. The strongest correlations were found between serum concentrations of IL- $1 \beta$ and IL1ra, IL-6, IL-8, and MIP-1 $\beta$, whereas the strongest correlations in CSF were found between endotoxin and IL-8, IL-17, MIP-1 $\beta$, and MCP-1. As was expected, the concentrations of inflammatory molecules in both serum and CSF significantly decreased after antibiotic treatment. With regard to kinetics, a severe course of IMD correlated positively with rapid declines of CSF IL-6 and cortisol levels. Sequential multiple analyses revealed patterns of inflammatory responses that were associated with the severity of IMD, as well as with the compartmentalization and kinetics of the immune reaction.

\section{Introduction}

Invasive meningococcal disease (IMD) still remains a lifethreatening infection with significant morbidity and mortality. This remains true even in developed countries, in spite of the availability of efficient antimicrobial therapy and intensive care treatment. IMD can present in four different clinical forms: benign meningococcemia (mortality rate $<1 \%$ ), meningitis (mortality rate $\sim 5 \%$ ), meningitis with sepsis (mortality rate $\sim 10 \%$ ), and fulminant meningococcal sepsis (FMS; mortality rate 40-50\%). Important mechanisms involved in IMD pathogenesis include the massive production of inflammatory mediators (i.e., complement factors, cytokines, etc.) and excessive activation of the coagulation and fibrinolysis pathways $[1,2]$. Exaggerated production of these mediators during the initial course of IMD is associated with high levels of meningococcal lipooligosaccharides (LOS) released into body fluids by Neisseria meningitidis, the causative agent of IMD [3]. High LOS concentrations are believed to be responsible for 
the over-stimulation of innate immunity through toll-like receptors (TLRs) and coagulation systems, leading to potentially fatal complications of IMD, which include multiple organ failure, septic shock, and disseminated intravascular coagulation with bleeding complications [4].

The principles of IMD management have been almost the same over the last few decades: rapid clinical diagnostics, immediate administration of efficient antibiotics, and transfer to a specialized intensive care unit (ICU). Novel therapies that can be used in the ICU setting include the administration of recombinant human activated protein $\mathrm{C}$ (rhAPC), which is indicated especially in adult patients with FMS without bleeding complications [5]. A significant effort has also been devoted to the neutralization of LOS. Unfortunately, the studies that have been conducted were not powerful enough to demonstrate improved survival $[6,7]$. Thus, no new therapies for IMD have been approved since the advent of rhAPC in 2001. Moreover, a clinical trial in children with IMD treated with rhAPC, which has both anti-inflammatory and anticoagulant properties, was inconclusive [8]. This lack of progress in the development of new therapies is partly due to our insufficient knowledge about the complexities of innate immunity responses during the course of IMD.

Therefore, the aim of our study was to better characterize the profiles of cytokines and other inflammatory mediators in the serum and cerebrospinal fluid (CSF) during IMD using a multiplex assay. We also assessed the relationship between the investigated mediators in both compartments and their correlation with IMD severity. Additionally, changes in these profiles after starting IMD therapy were evaluated.

\section{Patients and methods}

This study was conducted at the Teaching Hospital Bulovka, a 1,209-bed, tertiary care community hospital in Prague, Czech Republic. Enrolled patients were admitted to the Department of Infectious Diseases between the years 2004 and 2006. The study was approved by the local ethics committee, and it was performed in compliance with the Helsinki Declaration (1996 revision).

\section{Patients}

A cohort of 12 patients (five females and seven males) with IMD was analyzed. The mean age of the study subjects was 21 years (range 14-52 years). Table 1 presents the patient demographics and clinical parameters, as well as the characteristics of $N$. meningitidis strains determined by classical and molecular methods (i.e., polymerase chain reaction [PCR], genosubtyping, porA sequencing, and

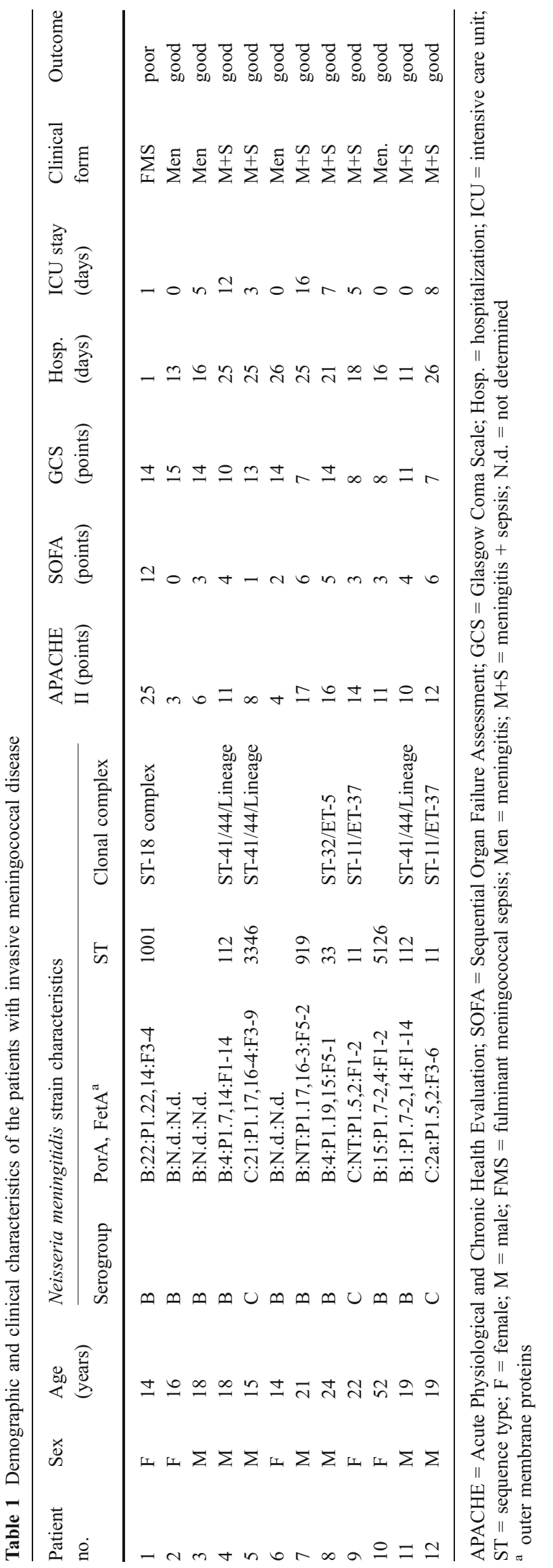


multilocus sequence typing) described elsewhere [9-12]. Patients' specimens (i.e., paired serum and CSF samples) were obtained at the time of diagnostic (day 1) and followup (day 3-5) lumbar puncture. Table 2 shows the patients' laboratory results from routine blood and CSF tests at day 1. CSF samples were collected in polystyrene tubes closed with screw-caps (Sarstedt AG, Germany) and venous blood was collected using an S-Monovette ${ }^{\circledR}$ (Sarstedt AG) collection system for blood count determination in tubes with $\mathrm{K}_{3}$-EDTA (Sarstedt AG). All samples were centrifuged immediately after collection, aliquoted, and stored at $-80^{\circ} \mathrm{C}$ until further analyses were performed. The patients were treated according to the national standard protocol, which consists of antibiotics (third-generation cephalosporins for meningitis and for sepsis + meningitidis or penicillin G for FMS), corticosteroids (for meningitis), and intensive care treatment, if required [13]. The disease severity was evaluated using the APACHE II (Acute Physiological and Chronic Health Evaluation), SOFA (Sequential Organ Failure Assessment), and GCS (Glasgow Coma Scale) scoring systems.

\section{Laboratory methods}

In addition to routine analyses (i.e., differential blood count, CSF cytology and chemistry, and serum level of Creactive protein $[\mathrm{S}-\mathrm{CRP}])$, serum and CSF concentrations of 14 biomarkers (i.e., interleukin-1 $\beta$ [IL-1 $\beta$ ], IL-1 receptor antagonist [IL-1ra], IL-2, IL-4, IL-5, IL-6, IL-8, IL-10, IL12, IL-17, tumor necrosis factor $\alpha[\mathrm{TNF}-\alpha]$, monocyte chemoattractant protein 1 [MCP-1], macrophage inflammatory protein $1 \beta[\mathrm{MIP}-1 \beta]$, and leptin) were analyzed using the Luminex ${ }^{\circledR}$ methodology with reagents from $R \& D$ Systems, Inc. (USA). Endotoxin concentrations were measured using the Kinetic LAL assay (Cambrex, USA).
Analyses of cortisol levels in the CSF and serum were performed by radioimmunometric assay using a commercial DSL-2000 kit (Diagnostic Systems Laboratories, USA) with a detection limit of $5 \mathrm{nmol} / \mathrm{l}$.

\section{Statistical methods}

Statistical analyses were performed using SPSS software ${ }^{\mathrm{TM}}$ (Jandel Scientific, USA). The data are presented as means (standard deviation). The analyses consisted of two-tailed tests with an $\alpha$-level below 0.05 . The differences between serum and CSF levels were tested using paired $t$-tests and Wilcoxon's signed rank test for nonparametric data. Spearman's and Pearson's correlation tests were employed to determine whether correlations existed between clinical and laboratory parameters.

\section{Results}

Cytokines, chemokines, leptin, and endotoxin in serum and CSF at admission

IL-1 $\beta$ was detected in the serum in $41 \%$ of patients $(5 / 12)$, whereas it was detected in the CSF in $100 \%$ of patients $(10 / 10)$. IL-1ra was detected in $100 \%$ of serum specimens $(12 / 12)$, as well as in $100 \%$ of CSF samples (10/10). IL-6 was detected in $91 \%$ of serum samples (11/12), whereas CSF concentrations were detectable in $100 \%$ of specimens (10/10). IL-10 was detectable in $75 \%$ of patients $(9 / 12)$ in the serum and in $90 \%$ of patients in the CSF (9/10). IL-17 was detected in $41 \%$ of serum specimens $(5 / 12)$ and in $50 \%$ of CSF samples $(5 / 10)$. TNF- $\alpha$ levels were detectable in the serum of only $25 \%$ of patients (3/12) and in the CSF in only $10 \%$ of the specimens $(1 / 10)$. IL-8 was detectable in $91 \%$ of serum specimens
Table 2 Inflammatory markers in (B) the blood and in the serum $(\mathrm{S})$ and cerebrospinal fluid (CSF) obtained at the time of diagnostic lumbar puncture from the patients with invasive meningococcal disease

$\mathrm{WBC}=$ white blood cells; Lympho = lymphocytes; Leuko = leukocytes; N.d. = not determined

\begin{tabular}{|c|c|c|c|c|c|c|}
\hline $\begin{array}{l}\text { Patient } \\
\text { no. }\end{array}$ & $\begin{array}{r}\text { S-CRP } \\
(\mathrm{mg} / \mathrm{l})\end{array}$ & $\begin{array}{l}\text { B-WBC } \\
\left(\text { cells } / \mathrm{mm}^{3}\right)\end{array}$ & $\begin{array}{l}\text { B-lympho } \\
\left(\text { cells } / \mathrm{mm}^{3}\right)\end{array}$ & $\begin{array}{l}\text { CSF-leuko } \\
\left(\text { cells } / 3 \mathrm{~mm}^{3}\right)\end{array}$ & $\begin{array}{l}\text { CSF-protein } \\
(\mathrm{g} / \mathrm{l})\end{array}$ & $\begin{array}{l}\text { CSF-glucose } \\
(\mathrm{mmol} / \mathrm{l})\end{array}$ \\
\hline 1 & 102 & 2,700 & 1,026 & 5 & 0.2 & 3.1 \\
\hline 2 & 204 & 17,600 & 1,232 & 8,704 & 2.7 & 2.5 \\
\hline 3 & 346 & 25,300 & 759 & 5,153 & 3.4 & 3.4 \\
\hline 4 & 92 & 4,700 & 376 & 230 & 2.4 & 2 \\
\hline 5 & 246 & 17,100 & 171 & 1,585 & 5.7 & 3.5 \\
\hline 6 & 225 & 21,500 & 215 & 10,000 & 2.6 & 4.4 \\
\hline 7 & 226 & 10,900 & 218 & 11,666 & 7.7 & 0.5 \\
\hline 8 & 233 & 25,200 & 252 & 3,331 & 1.8 & 0.5 \\
\hline 9 & 271 & 20,700 & 414 & 7,253 & 2.7 & 1.9 \\
\hline 10 & 159 & 16,900 & 507 & 3,413 & 2.6 & 3.3 \\
\hline 11 & 165 & 16,700 & 835 & 3,840 & 2.8 & 1.6 \\
\hline 12 & 265 & 21,500 & N.d. & 10,000 & 4.9 & 0.6 \\
\hline
\end{tabular}


(11/12) and in $100 \%$ of CSF samples (10/10). MCP-1 and MIP- $1 \beta$ were detected in $100 \%$ of serum samples (12/12) and in $100 \%$ of CSF specimens (10/10). Similarly, leptin was detectable in $100 \%$ of serum specimens (12/12) and $100 \%$ of CSF samples (10/10). In addition, endotoxin was detected in $25 \%$ of serum specimens (3/12) and in $90 \%$ of CSF samples $(9 / 10)$, and cortisol levels were detectable in all serum and CSF specimens. The serum and CSF concentrations and their statistical differences are shown in Table 3.

Correlation of serum and CSF inflammatory mediators with IMD severity

The APACHE II score on day 1 correlated with increased serum concentrations of IL-6 $(r=0.774, P=0.004)$ and IL1 ra $(r=0.648, P=0.031)$. The SOFA score on day 1 correlated only with IL-6 serum levels $(r=0.773, P=$ 0.004). In addition, the serum concentration of endotoxin correlated with GCS $(r=0.662, P=0.023)$. Unlike the concentrations of inflammatory molecules in the serum, the CSF concentrations were not associated with IMD severity.

Correlation between inflammatory mediators in the serum at admission

IL-1 $\beta$ serum levels correlated significantly with IL-1ra ( $r=$ 0.694, $P=0.017)$, IL-6 $(r=0.758, P=0.006)$, IL-8 $(r=0.773$, $P=0.004), \mathrm{IL}-10 \quad(r=0.656, P=0.026)$, and MIP-1 $\beta \quad(r=$ $0.877, P<0.001)$. IL-1ra demonstrated a significant correlation with IL-6 $(r=0.691, P=0.012)$, IL-10 $(r=0.606, P=$ $0.043)$, and MCP-1 $(r=0.809, P<0.001)$. IL-6 serum

Table 3 Difference between serum and CSF concentrations of inflammatory molecules in specimens obtained at admission to the hospital

\begin{tabular}{llll}
\hline Parameter & Serum & CSF & $P$-value \\
\hline IL-1b $(\mathrm{pg} / \mathrm{ml})$ & $38(112)$ & $974(1,118)$ & 0.031 \\
IL-1ra $(\mathrm{pg} / \mathrm{ml})$ & $27,978(14,234)$ & $58,710(33,025)$ & 0.029 \\
IL-6 $(\mathrm{pg} / \mathrm{ml})$ & $7,549(12,895)$ & $59,575(28,462)$ & $<0.001$ \\
IL-8 $(\mathrm{pg} / \mathrm{ml})$ & $2,263(5,325)$ & $33,760(19,118)$ & $<0.001$ \\
IL-10 $(\mathrm{pg} / \mathrm{ml})$ & $2,432(4,762)$ & $986(1,457)$ & N.s. \\
IL-17 $(\mathrm{pg} / \mathrm{ml})$ & $6(6)$ & $45(109)$ & N.s. \\
MCP-1 (pg/ml) & $2,139(2,592)$ & $23,025(14,134)$ & $<0.001$ \\
MIP-1b $(\mathrm{pg} / \mathrm{ml})$ & $653(1,657)$ & $49,207(42,336)$ & 0.006 \\
Leptin $(\mathrm{pg} / \mathrm{ml})$ & $6,496(8,846)$ & $53(42)$ & 0.002 \\
Endotoxin $(\mathrm{EU})$ & $13(43)$ & $133(140)$ & N.s. \\
Cortisol $(\mathrm{nmol} / \mathrm{ml})$ & $247(358)$ & $157(108)$ & N.s. \\
\hline
\end{tabular}

N.s. $=$ not significant; EU $=$ endotoxin unit

${ }^{a}$ Paired $t$-test and Wilcoxon signed rank test, as appropriate

Data are presented as means (standard deviation) concentrations correlated significantly with IL-8 $(r=0.773$, $P=0.004)$ IL-10 $(r=0.656, P=0.023)$, and MCP-1 $(r=$ $0.827, P<0.001)$. MCP-1 levels correlated with IL-8 and IL-10 serum concentrations $(r=0.709, P=0.013 ; r=0.715$, $P=0.011$, respectively). In addition, the serum concentrations of endotoxin correlated with the cortisol levels $(r=$ $0.695, P=0.017$ ).

Correlation between inflammatory mediators in the CSF at admission

IL-1 $\beta$ showed a significant correlation with the CSF levels of IL-10 $(r=0.636, P=0.043)$. IL-1 ra demonstrated a significant correlation with IL-6 $(r=0.867, P<0.001)$, IL$10(r=0.721, P=0.012)$, and MCP-1 $(r=-0.636, P=0.043)$. CSF IL-6 levels correlated with IL-10 $(r=0.758, P=0.009)$. Intrathecal levels of IL-8 demonstrated a significant correlation with MCP-1 $(r=0.879, P<0.001)$. Endotoxin concentrations in the CSF correlated with IL-8 $(r=0.778$, $P=0.005)$, IL-17 $(r=-0.623, P=0.048), \mathrm{MCP}-1 \quad(r=0.669$, $P=0.029)$, and MIP-1 $\beta(r=0.681, P=0.025)$. In addition, CSF cortisol levels correlated with IL-1 ra $(r=0.636$, $P=0.043)$, IL-6 $(r=0.721, P=0.016)$, and IL-10 $(r=0.697$, $P=0.022)$.

Kinetics of serum and CSF inflammatory mediators and the correlation with IMD severity

Significant decreases in serum concentrations 3-5 days after the start of the antibiotic treatment were detected for the following mediators: IL-1ra $(P=0.001)$, IL-6 $(P=$ 0.016), IL-10 $(P=0.023)$, and MIP-1 $\beta \quad(P=0.022)$. In addition, two routine biomarkers demonstrated significant changes during this interval: serum CRP levels decreased $(P<0.001)$, whereas the number of circulating lymphocytes increased $(P=0.002)$.

With regard to the kinetics of cytokines in CSF during the course of IMD, significant decreases were demonstrated in the concentrations of IL-1 $\beta(P=0.02)$, IL-1 ra $(P<0.001)$, IL-6 $(P<0.001)$, IL-8 $(P=0.008)$, MCP-1 $(P=0.001)$, and MIP-1 $\beta(P=0.003)$. The kinetics of serum as well as the CSF levels of IL-1ra, IL-6, MCP-1, and MIP-1 $\beta$ are shown in Fig. 1. Similar to cytokines and chemokines, the endotoxin levels decreased over time $(P=0.016)$. As expected, the number of leukocytes in the CSF as well as the CSF protein concentrations declined ( $P=0.003$ for both markers), and the CSF glucose level increased $(P=0.049)$.

Unlike serum parameters, the kinetics of some CSF biomarkers demonstrated a significant correlation with the IMD severity: $\Delta$ cortisol correlated with APACHE II score $(r=0.690, P=0.04)$ and $\Delta$ glucose and $\Delta$ IL-6 correlated with SOFA score $(r=-0.860, P=0.003 ; r=0.733, P=0.039$, respectively). 
Fig. 1 The kinetics of serum and cerebrospinal fluid (CSF) cytokine levels during invasive meningococcal disease
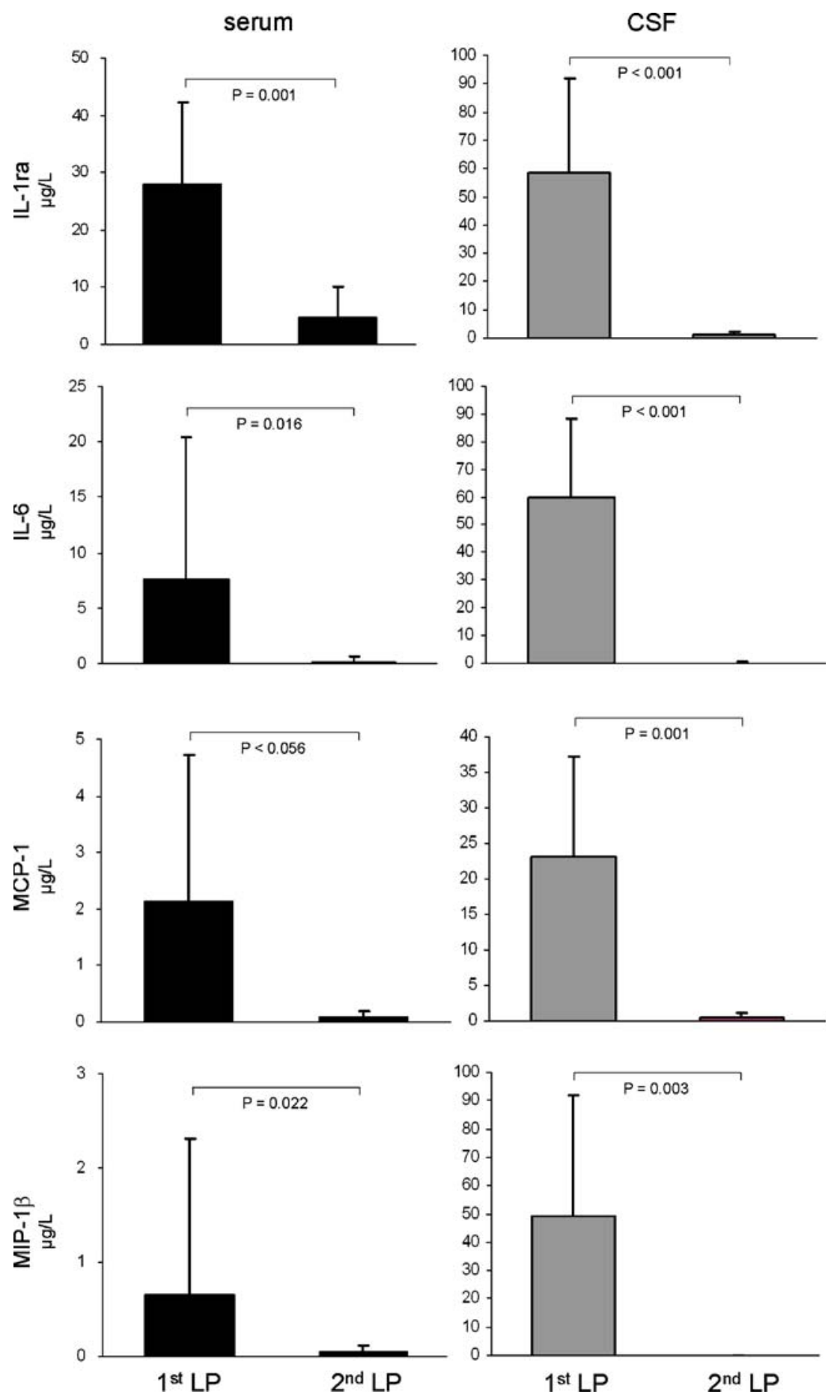

\section{Discussion}

The inflammatory response elicited by $N$. meningitidis is considered to be the major factor responsible for the outcome of IMD. Therefore, we analyzed the concentrations and kinetics of different molecules that are known to be related to inflammation in the CSF and serum during the course of IMD.
Our results demonstrated significant compartmentalization of the immune response in the subarachnoid space, which has been already reported in meningococcal meningitis, as well as in community-acquired bacterial meningitis of other etiology [14, 15]. Moreover, cytokines and chemokines that were concentrated in the CSF were also detectable in the serum in the majority of IMD patients. It is well known that IL- 6 and IL- 8 can be used in the laboratory 
diagnostics of bacterial meningitis and sepsis [16, 17]. However, our findings also indicate the potential use of IL$1 \mathrm{ra}, \mathrm{MCP}-1$, and MIP-1 $\beta$ for the laboratory diagnostics of sepsis, as well as bacterial meningitis. Similar to previous studies, we detected LOS in $90 \%$ of CSF specimens, whereas only $33 \%$ of serum samples were positive for $N$. meningitidis endotoxin [18]. This finding suggests that the inflammatory response in the brain is triggered by LOS, which is also supported by the significant correlation observed between high endotoxin levels in the CSF and increased intrathecal concentrations of IL-8, IL-17, MCP-1, and MIP$1 \beta$. It is likely that LOS released from $N$. meningitidis in the subarachnoid space activates brain-resident immune cells (e.g., microglia, meningeal macrophages, and macrophages in Virchow-Robin spaces). These cells produce chemokines after stimulation, the role of which is apparent: MCP-1 and MIP-1 $\beta$ attract monocytes to the subarachnoid space, whereas IL-8 is responsible for the migration of neutrophils $[19,20]$. In addition, high serum concentrations of MCP-1 and MIP- $1 \beta$ were detected in FMS, whereas meningococcal meningitis was associated with significantly lower concentrations of these chemokines [21].

The situation in the blood compartment is more complicated because LOS levels were detectable in only $1 / 4$ of the specimens, in spite of a significantly stimulated immune response. Thus, we can speculate about the stimulus that led to the systemic inflammation. It seems probable that the systemic response was elicited in our patients by LOS. The low or undetectable LOS levels measured in the blood of our patients with meningococcal meningitis can be explained by a low-grade bacterial load already found in patients with milder forms of IMD [22]. Another possible mechanism might be a rapid clearance of this molecule from the systemic circulation occurring via neutralization by host protein - bactericidal/permeabilityincreasing protein [23]. Finally, it might be possible that the triggers were proinflammatory cytokines released from the site of infection (i.e., the brain). However, this is unlikely, because focal infections such as meningitis or pneumonia are characterized by a highly compartmentalized immune response [15, 24].

It is generally believed that proinflammatory responses prevail at the site of the infection, whereas the systemic response is anti-inflammatory [25]. This idea partially conflicts with our findings of the highly elevated levels of anti-inflammatory mediators (i.e., IL-1ra, IL-10, and cortisol) in the CSF detected in the majority of our patients. In fact, we observed the simultaneous activation of intrathecal pro- and anti-inflammatory immune responses, which may reflect specific mechanisms of host responses in the brain. The role of chemokines in the subarachnoid space during bacterial meningitis has already been discussed. In addition, IL-6, which is produced in the brain by resident cells (i.e., astroglia and microglia) and migrating immune cells (i.e., neutrophils and macrophages), also has proinflammatory activities [26]. It is worth noting that this cytokine can stimulate the activity of glial cells, playing very important roles in the brain's defense against bacterial infection [27].

Despite the fact that meningitis was the prevailing clinical form of IMD in this study, the serum levels of IL6 only correlated positively with IMD severity evaluated at the time of admission to the hospital. Waage et al. [28] previously reported similar findings in patients with a fatal course of IMD. In agreement with their results, we observed extremely high IL-6 serum levels in a patient (patient 1; Table 1) who died as a result of FMS [29]. When we assessed for an association between the kinetics of IL-6 and IMD severity, no correlation was found. Conversely, we observed different results in the CSF, with a significant correlation of IMD severity and kinetics of IL-6 and cortisol, and no correlation with their baseline levels. This is partially in discrepancy with the results of one study in which high baseline CSF cortisol levels were detected in patients with a severe course of adult community-acquired bacterial meningitis [15]. This difference is probably due to an alteration in cortisol metabolism during IMD. The observed correlation between the rapid decline of CSF IL6 levels and IMD severity is a novel finding, which contradicts previous reports of persistent IL- 6 activity in the CSF of children with bacterial meningitis [30].

In conclusion, our data illustrate the complex relationship between proinflammatory and anti-inflammatory responses during the course of IMD. The differences observed between the investigated biomarkers with regard to their kinetics, correlation with IMD severity, compartmentalization of production, as well as their complex relationships, warrant a careful approach in the study of IMD pathophysiology. Multiplex assays seem to be a good option for studies of these complexities.

Acknowledgments The study was supported by the Ministry of Education, Youth, and Sports of the Czech Republic, grant no. MSM0021620806, and by the Internal Grant Agency of the Ministry of Health of the Czech Republic, grant no. NR/9316-3. The authors thank M. Helcl, MD, J. Príhodová, MD, and Z. Blechova, MD, for their help with the patient enrollment (Teaching Hospital Bulovka, Prague, Czech Republic).

Open Access This article is distributed under the terms of the Creative Commons Attribution Noncommercial License which permits any noncommercial use, distribution, and reproduction in any medium, provided the original author(s) and source are credited.

\section{References}

1. van Deuren M, Brandtzaeg P, van der Meer JWM (2000) Update on meningococcal disease with emphasis on pathogenesis and clinical management. Clin Microbiol Rev 13:144-166 
2. van Deuren M, van der Ven-Jongekrijg J, Vannier E, van Dalen R, Pesman G, Bartelink AK, Dinarello CA, van der Meer JW (1997) The pattern of interleukin-1beta (IL-1beta) and its modulating agents IL-1 receptor antagonist and IL-1 soluble receptor type II in acute meningococcal infections. Blood 90:1101-1108

3. Lehner PJ, Davies KA, Walport MJ, Cope AP, Würzner R, Orren A, Morgan BP, Cohen J (1992) Meningococcal septicaemia in a C6-deficient patient and effects of plasma transfusion on lipopolysaccharide release. Lancet 340:1379-1381. doi:10.1016/ 0140-6736(92)92561-S

4. Brandtzaeg P, Bjerre A, Øvstebø R, Brusletto B, Joø GB, Kierulf P (2001) Neisseria meningitidis lipopolysaccharides in human pathology. J Endotoxin Res 7:401-420

5. Dellinger RP, Carlet JM, Masur H, Gerlach H, Calandra T, Cohen J, Gea-Banacloche J, Keh D, Marshall JC, Parker MM, Ramsay G, Zimmerman JL, Vincent JL, Levy MM (2004) Surviving Sepsis Campaign guidelines for management of severe sepsis and septic shock. Intensive Care Med 30:536-555. doi:10.1007/ s00134-004-2210-Z

6. Derkx B, Wittes J, McCloskey R (1999) Randomized, placebocontrolled trial of HA-1A, a human monoclonal antibody to endotoxin, in children with meningococcal septic shock. European Pediatric Meningococcal Septic Shock Trial Study Group. Clin Infect Dis 28:770-777. doi:10.1086/515184

7. Levin M, Quint PA, Goldstein B, Barton P, Bradley JS, Shemie SD, Yeh T, Kim SS, Cafaro DP, Scannon PJ, Giroir BP (2000) Recombinant bactericidal/permeability-increasing protein (rBPI21) as adjunctive treatment for children with severe meningococcal sepsis: a randomised trial. rBPI21 Meningococcal Sepsis Study Group. Lancet 356:961-967. doi:10.1016/S0140-6736(00)02712-4

8. Goldstein B, Nadel S, Peters M, Barton R, Machado F, Levy H, Haney DJ, Utterback B, Williams MD, Giroir BP (2006) ENHANCE: results of a global open-label trial of drotrecogin alfa (activated) in children with severe sepsis. Pediatr Crit Care Med 7:200-211. doi:10.1097/01.PCC.0000217470.68764.36

9. Taha MK, Alonso JM, Cafferkey M, Caugant DA, Clarke SC, Diggle MA, Fox A, Frosch M, Gray SJ, Guiver M, Heuberger S, Kalmusová J, Kesanopoulos K, Klem AM, Kriz P, Marsh J, Mölling P, Murphy K, Olcén P, Sanou O, Tzanakaki G, Vogel U (2005) Interlaboratory comparison of PCR-based identification and genogrouping of Neisseria meningitidis. J Clin Microbiol 43:144-149. doi:10.1128/JCM.43.1.144-149.2005

10. Russell JE, Jolley KA, Feavers IM, Maiden MC, Suker J (2004) PorA variable regions of Neisseria meningitidis. Emerg Infect Dis 10:674-678

11. Mölling P, Unemo M, Bäckman A, Olcén P (2000) Genosubtyping by sequencing group $\mathrm{A}, \mathrm{B}$ and $\mathrm{C}$ meningococci; a tool for epidemiological studies of epidemics, clusters and sporadic cases. APMIS 108:509-516. doi:10.1034/j.1600-0463.2000.d01-90.x

12. Thompson EA, Feavers IM, Maiden MC (2003) Antigenic diversity of meningococcal enterobactin receptor FetA, a vaccine component. Microbiology 149:1849-1858. doi:10.1099/mic.0.26131-0

13. Kasal E, Roznovsky L, Krízová P, Dzupová O, Dostal V, Struncova V, Chytra I, Barnetova D, Habanec T, Plisek S, Chalupa P (2005) Therapeutic protocol of invasive meningococcal disease (IMD). Prakt Lek 85:196-199

14. Waage A, Halstensen A, Espevik T, Brandtzæg P (1993) Compartmentalization of TNF and IL-6 in meningitis and septic shock. Mediators Inflamm 2:23-25. doi:10.1155/S096293519300002X

15. Holub M, Beran O, Dzupová O, Hnyková J, Lacinová Z, Príhodová J, Procházka B, Helcl M (2007) Cortisol levels in cerebrospinal fluid correlate with severity and bacterial origin of meningitis. Crit Care 11:R41. doi:10.1186/cc5729

16. Kleine TO, Zwerenz P, Zöfel P, Shiratori K (2003) New and old diagnostic markers of meningitis in cerebrospinal fluid (CSF). Brain Res Bull 61:287-297. doi:10.1016/S0361-9230(03)00092-3

17. Herzum I, Renz H (2008) Inflammatory markers in SIRS, sepsis and septic shock. Curr Med Chem 15:581-587. doi:10.2174/ 092986708783769704

18. Brandtzaeg P, Ovstebøo R, Kierulf P (1992) Compartmentalization of lipopolysaccharide production correlates with clinical presentation in meningococcal disease. J Infect Dis 166:650-652

19. Møller AS, Bjerre A, Brusletto B, Joø GB, Brandtzaeg P, Kierulf P (2005) Chemokine patterns in meningococcal disease. J Infect Dis 191:768-775. doi:10.1086/427514

20. Sterka D Jr, Rati DM, Marriott I (2006) Functional expression of NOD2, a novel pattern recognition receptor for bacterial motifs, in primary murine astrocytes. Glia 53:322-330. doi:10.1002/glia. 20286

21. Cavaillon JM (2003) Proinflammatory and anti-inflammatory cytokines as mediators of Gram-negative sepsis. In: Kotb M, Calandra T (eds) Cytokines and chemokines in infectious diseases handbook, 1st edn. Humana Press Inc., Totowa, New Jersey, pp 33-37

22. Hackett SJ, Guiver M, Marsh J, Sills JA, Thomson AP, Kaczmarski EB, Hart CA (2002) Meningococcal bacterial DNA load at presentation correlates with disease severity. Arch Dis Child 86:44-46. doi:10.1136/adc.86.1.44

23. Elsbach P (1998) Recent advances in therapy of sepsis: focus on recombinant bactericidal/permeability-increasing protein (BPI). BioDrugs 9:435-442. doi:10.2165/00063030-199809060-00001

24. Dehoux MS, Boutten A, Ostinelli J, Seta N, Dombret MC, Crestani B, Deschenes M, Trouillet JL, Aubier M (1994) Compartmentalized cytokine production within the human lung in unilateral pneumonia. Am J Respir Crit Care Med 150:710-716

25. Munford RS, Pugin J (2001) Normal responses to injury prevent systemic inflammation and can be immunosuppressive. Am J Respir Crit Care Med 163:316-321

26. Wen LL, Chiu CT, Huang YN, Chang CF, Wang JY (2007) Rapid glia expression and release of proinflammatory cytokines in experimental Klebsiella pneumoniae meningoencephalitis. Exp Neurol 205:270-278. doi:10.1016/j.expneurol.2007.02.011

27. Kielian T, Mayes P, Kielian M (2002) Characterization of microglial responses to Staphylococcus aureus: effects on cytokine, costimulatory molecule, and Toll-like receptor expression. J Neuroimmunol 130:86-99. doi:10.1016/S0165-5728(02) 00216-3

28. Waage A, Brandtzaeg P, Halstensen A, Kierulf P, Espevik T (1989) The complex pattern of cytokines in serum from patients with meningococcal septic shock. Association between interleukin 6, interleukin 1, and fatal outcome. J Exp Med 169:333-338. doi:10.1084/jem.169.1.333

29. Holub M, Scheinostová M, Dzupová O, Fiserová A, Beran O, Kalmusová J, Musilek M, Krízová P (2007) Neisseria meningitidis strains from patients with invasive meningococcal disease differ in stimulation of cytokine production. Folia Microbiol (Praha) 52:525-528. doi:10.1007/BF02932114

30. Rusconi F, Parizzi F, Garlaschi L, Assael BM, Sironi M, Ghezzi P, Mantovani A (1991) Interleukin 6 activity in infants and children with bacterial meningitis. The Collaborative Study on Meningitis. Pediatr Infect Dis J 10:117-121. doi:10.1097/00006454-19910 2000-00008 